\title{
The Occurrence and Infectivity of Arbuscular Mycorrhizal Fungi in Inoculated and Uninoculated Rhizosphere Soils of Two-year-old Commercial Grapevines.
}

\author{
A.H. Meyer ${ }^{1}$, A. Botha ${ }^{2 *}$, A.J. Valentine ${ }^{3}$, E. Archer ${ }^{4}$ and P.J.E. Louw ${ }^{1}$ \\ (1) ARC Infruitec-Nietvoorbij, Private Bag X5026, 7599 Stellenbosch, South Africa \\ (2) Department of Microbiology, Stellenbosch University, Private Bag X1, 7602 Matieland (Stellenbosch), South Africa \\ (3) Department of Botany, Stellenbosch University, Private Bag X1, 7602 Matieland (Stellenbosch), South Africa \\ (4) Department of Viticulture and Oenology, Stellenbosch University, Private Bag X1, 7602 Matieland (Stellenbosch), South Africa
}

Submitted for publication: November 2004

Accepted for publication: September 2005

Key words: Acaulospora, Glomus, indigenous AM fungi, phosphorous, vines

\begin{abstract}
Arbuscular mycorrhizal (AM) fungal populations present in the rhizosphere of vine roots in the vineyards of a commercial farm in the Stellenbosch Region were investigated using microscopic analyses. AM root colonisation levels of between $70 \%$ and $90 \%$ were found in both grapevine roots that were previously artificially inoculated with commercial AM inocula, and in uninoculated (control) grapevine roots. The AM fungal isolates in the rhizosphere soil, identified using morphological criteria, belonged to the genera Acaulospora, Gigaspora, Glomus, Sclerocystis and Scutellospora. The majority of species found was not present in the commercial inocula and was either indigenous to the vineyard or originated from the nursery where the vines were obtained. Isolates of Glomus and Acaulospora appeared to be the most abundant. The AM fungal species occurred at a soil phosphorus $(P)$ concentration of up to $80 \mathrm{mg} / \mathrm{kg} \mathrm{P}$ and a soil $\mathrm{pH}(\mathrm{KCl})$ that ranged between 5.63 and 6.10. Total spore counts ranged between 1000 and 3779 spores/100 g dry soil. In accordance with literature, lower spore concentrations were recorded for the heavier soil types with no cover crop system, compared with the sandy soil type on which cover crops were sown annually.
\end{abstract}

Some agricultural soils, particularly those deficient in beneficial soil organisms, due in part to side effects of practices such as fumigation, require reconditioning to render them suitable for optimum crop performance. From time to time, artificial inoculation with selected arbuscular mycorrhizal (AM) fungi is used to reintroduce these fungi to such soils (Abbott \& Robson, 1982; Menge, 1983).

It is generally accepted that AM colonisation of vine roots contributes to the optimum performance of grapevines (Possingham \& Groot Obbink, 1971; Karagiannidis et al., 1995; Karagiannidis et al., 1997). It is for this reason that commercial AM fungal strains have been available to farmers abroad for nearly two decades (Menge, 1983). However, large-scale inoculation of cultivated crops in South Africa only emerged recently (M. Venter, personal communication, 2000) and there is little known about the mycorrhizal status of SA vineyard soils.

In a previous study, AM root colonisation and subsequent host plant response in young grapevines of a commercial vineyard were determined after artificial inoculation with AM fungi (Meyer et al., 2004). It was, however, found that grapevine roots were adequately colonised with indigenous populations of AM fungi. Consequently, no significant improvement in the performance of most of the young grapevines could be detected, since it was believed that these fungi masked the effects of inoculation.

To obtain additional information on the mycorrhizal status of the vineyard, including the diversity and abundance of indigenous species, AM fungal spores isolated from trap pot cultures, prepared from the inoculated and uninoculated (control) grapevine rhizosphere soils, were identified using morphological criteria. In addition, AM fungal root colonisation patterns in roots from the trap pot cultures and the field-grown vines were studied and spores obtained from the field were quantified.

\section{MATERIALS AND METHODS}

Experiment layout and experiment procedures were described previously (Meyer et al., 2004). Briefly, the study was carried out in a commercial Merlot vineyard, grafted onto three different rootstocks. The first two, i.e. 101-14 Mgt and 110 Richter (110 $\mathrm{R})$, were planted on a ridged Westleigh soil and the third, 99 Richter (99 R), on an unridged Fernwood soil (Soil Classification Working Group, 1991). Five treatments were applied at the time of planting. Three of the treatments (Biocult ${ }^{\circledR}$, Glomus sp. 1054 and Vaminoc $\left.{ }^{\circledR}\right)$ each involved inoculation with different AM inoculums. The nutrient-rich Biocult ${ }^{\circledR}$ was compiled of spores and other infective propagules belonging to Glomus mosseae, Glomus intraradices, Glomus fasciculatum, Glomus etunicatum, Acaulosporae spp. and Trichoderma. The total number of spores in this inoculum amounted to $c a 160$ per $50 \mathrm{~mL}$. The Glomus sp. 1054 inoculum, consisting of soil amended with colonised roots, containing ca 7200 spores per $50 \mathrm{~mL}$. The Vaminoc inoculum contained a total of $\mathrm{ca} 920$ spores in $5 \mathrm{~g}$ clay amended medium. These spores represented the species G. mosseae, G. fasciculatum, G. caledonium and Glomus versiforme. The fourth treatment

Corresponding author: E-mail address: abo@sun.ac.za

Acknowledgements: The authors wish to thank Winetech, the National Research Foundation of South Africa, the Agricultural Research Council and Stellenbosch University for financial support. The authors are also grateful to the staff of the Soil Science division at Nietvoorbij for their technical support. 
involved sterilisation of soil by a combination of fungicides, Benlate ${ }^{\circledR}$ WP and Rovral Flo ${ }^{\circledR} \mathrm{SC}$, in order to establish a control not affected by soil fungi. The fifth treatment (control) received neither fungicides nor AM inocula. All treatments, except the one where nutrient-rich Biocult was used as AM inoculum, received $50 \mathrm{~mL}$ per vine of sterilised Biocult (steam sterilised in an autoclave at $121^{\circ} \mathrm{C}, 100 \mathrm{kPa}$, for 60 minutes) to ensure that all vines received the same amount of nutrients. In the present study, the procedures below were followed.

\section{Sampling procedures and establishment of trap pot cultures}

In winter (June 2000) composite soil samples, representative of each rootstock, were taken at the following soil depths: 0-150 $\mathrm{mm}, 150-300 \mathrm{~mm}, 300-600 \mathrm{~mm}$ and $600-900 \mathrm{~mm}$. Soil analyses were carried out in accordance with methods prescribed by The Non-affiliated Soil Analysis Work Committee (1990). In addition, rhizosphere soil and roots of each of the four replicates per treatment were sampled. Roots were stored in $50 \%(\mathrm{v} / \mathrm{v})$ ethanol at room temperature until analysed. Each soil sample ( $c a 1.5 \mathrm{~kg}$ ) was divided into two sub-samples. The one sub-sample ( $c a 1 \mathrm{~kg}$ ) was air-dried for three weeks, before it was subjected to microscopic analyses.

The other sub-sample ( $c$ a $500 \mathrm{~g}$ ) was subjected to a cold shock treatment for approximately six weeks at $0^{\circ} \mathrm{C}$ to enhance germination amongst spores that were dormant at the time of field collection (Vimard et al., 1999). Thereafter, each of these $500 \mathrm{~g}$ cold shocked, sub-samples was mixed with $500 \mathrm{~g}$ sterilised sand (gamma-irradiated at a minimum absorbed dose of $20 \mathrm{kGy}$ per $\mathrm{kg}$ soil) and transferred to a free-draining pot. Surface sterilised grain sorghum seeds, treated with $5 \%(\mathrm{v} / \mathrm{v})$ hypochlorite solution for 20 minutes, were sown onto these pots, covered with a thin layer of sand, and watered to field capacity. No nutrients were added to the potting mixture. Pot cultures were watered on a supplementary basis via a splash-free drip irrigation system to permit limited drainage from each pot. All possible precautions were taken to minimise the likelihood of contamination. The $\mathrm{pH}(\mathrm{KCl})$ of the potting mixture was $c a$ 5.9. Pot plants were allowed to reach maximal growth (after eight to twelve weeks) at which time roots and soils were sampled for microscopic examination.

\section{Microscopic analyses of roots and spores}

The level of root colonisation by AM fungi was estimated in the field-collected vine roots using a compound microscope as described by Brundrett et al. (1994). Both the field-collected vine roots, as well as the sorghum roots from the trap pot cultures, were used to identify root colonisation patterns and diagnostic structural features of the AM fungi.

Spores were separated from the soil in the trap pot cultures using wet sieving and sucrose gradient centrifugation (Brundrett et al., 1994). These spores were then selected and grouped according to morphological types using dissecting microscopy. Subsequently, semi-permanent microscope slide preparations of the spores were made. Spores were stained and mounted in Melzer's reagent and Polyvinyl-Lacto-Glycerol (PVLG). Using a compound microscope, the spores were then identified according to the methods in Brundrett et al. (1996) and the INVAM website (Morton, 2001). The same method was used to separate AM spores in the air-dried sub-samples. These spores were then enumerated using a stereo microscope (Nikon SMZ -10A). Counts were expressed as the total number of spores per $100 \mathrm{~g}$ of dry field soil and included both dead and viable spores.

\section{Statistical procedure}

Statgraphics version 7 and SAS version 6.12 packages were used for the statistical analyses of the data:

1. The percentage data (root colonisation data) were arcsine transformed (Zar, 1981). The influence of the factors and their interactions were tested with a two-way analysis of variance (2-way ANOVA). Where the ANOVA revealed significant effects by the factors, the differences between treatments were separated using a post hoc least significant difference (LSD), multiple comparison test $(\mathrm{p} \leq 0.05)$. Data for each rootstock were analysed separately.

2. The rest of the data were analysed with SAS version 6.12 (SAS, 1990). The influence of the factors and their interactions were tested with a 2-way ANOVA. The analysis was done for each rootstock separately and with rootstock as a factor. For the ANOVA with rootstock as a factor, treatments were used as a sub-plot factor. Fisher's Least Significance Differences were calculated at the $5 \%$ significance level to compare treatment means. Shapiro-Wilks's test was performed to test for non-normality (Shapiro and Wilk, 1965).

\section{RESULTS AND DISCUSSION}

From the results obtained during the 1998/99-season, it was evident that AM fungal strains, other than those included in the inocula, were colonising the vine roots (Meyer et al., 2004). This resulted in a relatively high level of AM fungal root colonization of between $40 \%$ and $85 \%$. During the 1999/00-season, higher levels of root colonisation were obtained, ranging between $70 \%$ and $90 \%$ (Fig. 1). The modes by means of which the AM fungi spread through the root cortex were typical of the Paris- and Arum- types (Gallaud, 1905), which were, respectively, characterised by the formation of noticeable intracellular coils in the cortical tissue and a relatively parallel spreading of intercellular hyphae. Growth of the co-existing fungal species in the roots did not seem to have been affected by the prevailing high levels of soil P, up to $80 \mathrm{mg} / \mathrm{kg} \mathrm{P}$ (Table 1). Furthermore, this soil P-level was much higher than the level of about $7 \mathrm{mg} / \mathrm{kg} \mathrm{P}$, above which inhibition of fungal development in roots can be expected (Brundrett et al., 1996). This tolerance of AM fungi to relatively high levels of soil $\mathrm{P}$ is in agreement with results from other studies (Plenchette et al., 1983; Schubert et al., 1990).

In the present study, $18 \mathrm{AM}$ fungal species were obtained, of which 15 were positively identified on the basis of spore morphology and other diagnostic fungal structures (Table 2). These

\section{TABLE 1}

Soil P analyses of 101-14 Mgt, 110 R and 99 R rootstock plots (1999/00 season).

\begin{tabular}{cccc}
\hline & \multicolumn{3}{c}{$\mathbf{P}(\mathbf{m g} / \mathbf{k g})$} \\
\hline Soil depth (mm) & $\mathbf{1 0 1 - 1 4} \mathbf{~ M g t}$ & $\mathbf{1 1 0 ~ R}$ & $\mathbf{9 9} \mathbf{~ R}$ \\
\hline $0-150$ & 74 & 68 & 63 \\
$150-300$ & 80 & 61 & 67 \\
$300-600$ & 27 & 31 & 61 \\
$600-900$ & 15 & 6 & 50 \\
\hline
\end{tabular}




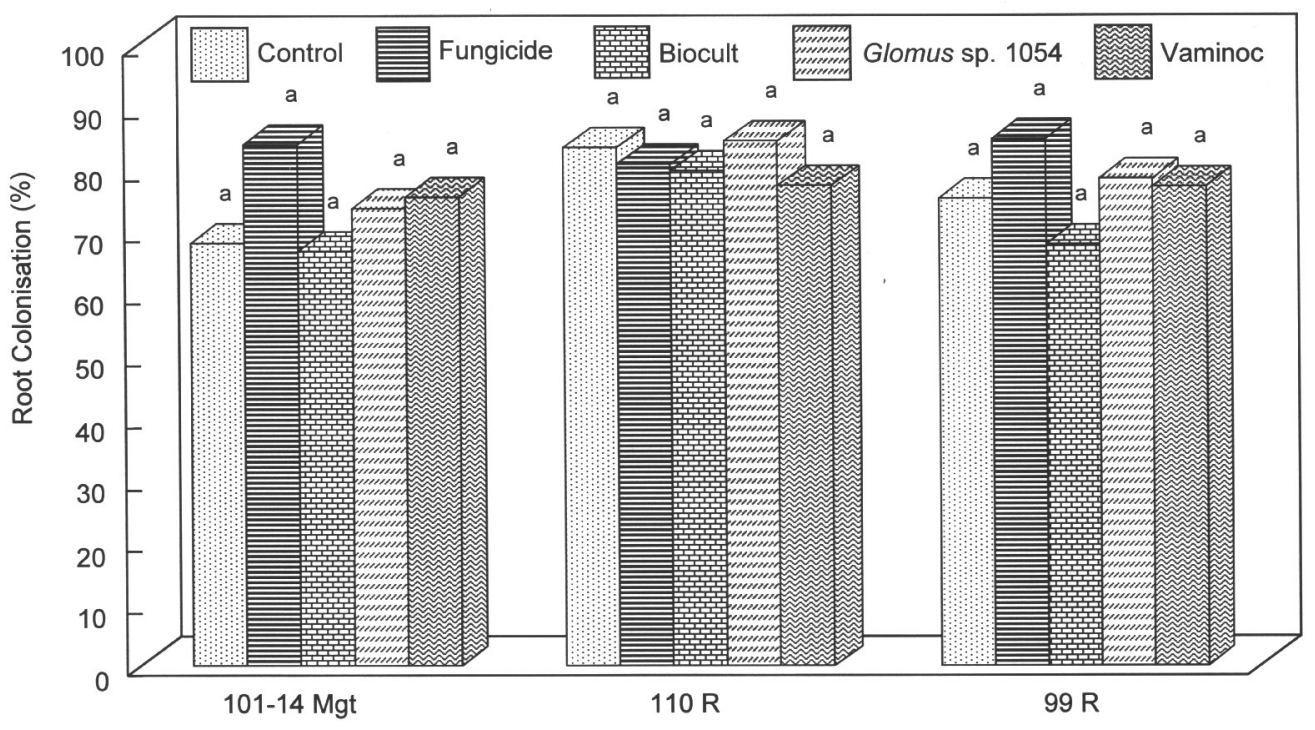

FIGURE 1

Maximum percentage of arbuscular mycorrhizal (AM) root colonisation of two-year-old Merlot grafted onto three different rootstocks (1999/00-season). a, b: Values accompanied by a common letter per rootstock do not differ significantly at the $5 \%$ level.

species were present in the rhizosphere soils of both the inoculated and uninoculated (control) grapevines. There was considerable overlap in the species composition for the different treatments of each rootstock. Seven of the 18 species occurred at all the sites, namely: Acaulospora spinosa, Gigaspora gigantea, Glomus mosseae, Glomus sinuosum, Scutellospora calospora, Scutellospora dipurpurascens and Scutellospora fulgida. One species, Gigaspora decipiens, occurred in the soil of rootstock 101-14 Mgt, but was not detected in the other soils. This may indicate a specific association between this rootstock and $G$. decipiens, as all vines were obtained from the same nursery. The rest of the species mentioned in Table 2 were not associated with a specific treatment. Most of the AM fungal species detected belonged to the genera Glomus, Acaulospora, Scutellospora and Gigaspora, and were similar to those obtained from the soil of a vineyard located in northern Greece (Karagiannidis \& Nikolaou, 1999).

In the present study, spores of Acaulospora spinosa and smallspored species of the genus Glomus listed in Table 2 accounted for the major proportion of the total volume of spores per sampling site. This is in agreement with other work, in which it was found that members of the genus Glomus commonly occur in field samples collected from vineyard soils (Karagiannidis et al., 1997; Karagiannidis \& Nikolaou, 1999). Although large spores of Gigaspora gigantea and Scutellospora species were frequently encountered at the various sampling sites, these spores accounted only for a minor proportion ( $\mathrm{ca} 5 \%$ ) of the total volume of spores per sampling site.

In a study by Franke-Snyder et al. (2001), where a range of agricultural soils and crops was investigated, Gigaspora gigantea was found to be present at higher spore concentration levels. It accounted for more than $60 \%$ of the total spore volume. The lower spore numbers of Gigaspora gigantea in the present study may be partially explained in terms of shifts induced in AM fun- gal communities due to the application of nitrogen fertiliser. This was demonstrated elsewhere in fertilisation experiments, where increased nitrogen application was associated with the displacement of large-spored species of Scutellospora and Gigaspora by small-spored Glomus species (Egerton-Warburton \& Allen, 2000). In the latter study, the nitrogen application level was about $60 \mathrm{~kg} / \mathrm{ha} / \mathrm{yr}$, which is comparable to the $75 \mathrm{~kg} / \mathrm{ha} / \mathrm{yr}$ applied in this study.

It is important to note that only 5 out of the 18 species isolated from the vineyard soil were included in the original inocula. The rest of the species were indigenous to the vineyard and/or originated from the nursery from which the vines were obtained. Due to close similarity of morphological features between isolates of the same species (Abbott \& Robson, 1982), it was impossible, using the methods employed in this study, to distinguish with certainty whether Glomus etunicatum, Glomus intraradices, Glomus mosseae, Acaulospora scrobiculata and Acaulospora spinosa, detected at the inoculated sites, could have originated from the Biocult and Vaminoc inocula. These species also occurred in the uninoculated soils, and similar levels of AM root colonisation were observed in the uninoculated and inoculated vine roots. Therefore, it can be assumed that the use of these species in the inocula did not result in higher levels of root colonisation. The other AM species present in the inocula, which can be positively identified using the criteria in this study, i.e. Glomus caledonium, Glomus fasciculatum and Glomus versiforme, were arguably either outperformed by the indigenous AM fungal species, or the vine roots were preferably susceptible for infection by indigenous AM fungi compared to these fungal species. A better interpretation of these results would have been possible if the infectivity potential of the individual AM strains in the inocula were measured prior to field inoculation and also if the number of spores per strain in the inocula was known. 
TABLE 2

AM fungal species identified in the rhizosphere soils of 101-14 Mgt, $110 \mathrm{R}$ and 99 R rootstock blocks (1999/00-season).

\begin{tabular}{|c|c|c|c|c|c|c|c|c|c|c|c|c|c|c|c|}
\hline \multirow{2}{*}{$\begin{array}{l}\text { AM fungal species: } \\
(+) \text { Present or (-) absent } \\
\text { at the different treatments (T) }\end{array}$} & \multicolumn{5}{|c|}{ 101-14 Mgt } & \multicolumn{5}{|c|}{$110 \mathrm{R}$} & \multicolumn{5}{|c|}{$99 R$} \\
\hline & $\mathbf{T 1}$ & $\mathbf{T} 2$ & T3 & T4 & T5 & $\mathbf{T 1}$ & $\mathbf{T} 2$ & T3 & T4 & $\mathbf{T 5}$ & $\mathbf{T 1}$ & $\mathbf{T} 2$ & $\mathbf{T 3}$ & T4 & T5 \\
\hline Acaulospora scrobiculata & + & - & - & - & - & - & - & - & - & - & - & - & - & + & + \\
\hline Acaulospora spinosa & + & + & + & + & + & + & + & + & + & + & + & + & + & + & + \\
\hline Gigaspora sp. & - & - & - & - & - & - & - & + & - & - & - & + & - & - & - \\
\hline Gigaspora gigantea & + & + & + & + & + & + & + & + & + & + & + & + & + & + & + \\
\hline Gigaspora decipiens & + & + & + & + & + & - & - & - & - & - & - & - & - & - & - \\
\hline Glomus clavisporum & - & - & + & - & - & + & - & + & + & + & + & + & - & + & + \\
\hline Glomus etunicatum & + & - & + & - & - & + & - & + & - & + & + & - & + & - & - \\
\hline Glomus intraradices & + & + & + & - & - & - & - & + & + & - & + & + & + & - & + \\
\hline Glomus mosseae & + & + & + & + & + & + & + & + & + & + & + & + & + & + & + \\
\hline Glomus sinuosum & + & + & + & + & + & + & + & + & + & + & + & + & + & + & + \\
\hline Glomus tortuosum & - & - & - & - & - & - & - & - & - & - & + & + & - & - & - \\
\hline Sclerocystis sp. & - & - & - & - & - & - & + & - & - & - & + & + & - & - & - \\
\hline Scutellospora sp. & - & - & - & - & - & - & - & - & - & - & + & + & - & - & - \\
\hline Scutellospora calospora & + & + & + & + & + & + & + & + & + & + & + & + & + & + & + \\
\hline Scutellospora cerradensis & + & - & - & - & - & - & - & - & + & - & - & - & - & - & - \\
\hline Scutellospora dipurpurascens & + & + & + & + & + & + & + & + & + & + & + & + & + & + & + \\
\hline Scutellospora erithropa & - & + & - & - & - & - & - & - & - & - & - & - & - & - & - \\
\hline Scutellospora fulgida & + & + & + & + & + & + & + & + & + & + & + & + & + & + & + \\
\hline
\end{tabular}

$\mathrm{T} 1=$ Control (uninoculated vines)

$\mathrm{T} 2=$ Fungicide treatment

$\mathrm{T} 3$ = Biocult

$\mathrm{T} 4=$ Glomus $\mathrm{sp} .1054$

$\mathrm{T} 5$ = Vaminoc

High spore concentrations of between 1000 and 3779 spores/100 g dry soil were observed during June 2000 (Table 3). Since spore concentrations are often higher during wet, rainy seasons than during dry seasons (Allen et al., 1998; Schwob et al., 1999; Picone, 2000), a decrease in the spore concentration was likely during the dry summer months normally experienced in the study area. The $\mathrm{pH}$ values $(\mathrm{KCl})$ of soil from the spore sampling sites ranged between 5.63 and 6.10 (Table 3 ) and did not seem to have had a negative impact on spore abundance. It is known that most AM fungal species occur in soils around and above a neutral pH (Schubert \& Cravero, 1985).

Spore numbers in soils may also indicate the ability of those soils to support infection of plant roots by AM fungi (Schubert \& Cravero, 1985). The high spore numbers correlated well with the relatively high level of root colonisation, between $70 \%$ and $90 \%$ (Fig. 1). At the various sampling sites of each treatment per rootstock, there was no indication of a significant increase in spore numbers as a direct result of inoculation with commercial AM fungal species. Both the inoculated and uninoculated rhizosphere soils contained similar levels of spore concentrations (Table 3). The fungicide treatment resulted in a significant increase in the number of spores in the rhizosphere soils of 101-14 Mgt vines compared with the rhizosphere soils that received the commercial inocula, Biocult and Vaminoc (Table 3). The application of fungicides might have resulted in a reduction in hyperparasites, predators, or competing plant parasites, which could have encouraged rapid growth and dispersion of AM fungi (Menge, 1982).

\section{TABLE 3}

Spore concentrations of AM fungi and $\mathrm{pH}$ values measured at different soil plots of 101-14 Mgt, $110 \mathrm{R}$ and $99 \mathrm{R}$ rootstock cultivars (1999/00-season).

\begin{tabular}{lcc}
\hline Treatment & Spore count $(/ \mathbf{1 0 0 g}$ dry soil) & pH (KCI) \\
\hline 101-14 Mgt & & \\
Control & $1296 \mathrm{ab}$ & $5.80 \mathrm{a}$ \\
Fungicide & $1458 \mathrm{a}$ & $5.78 \mathrm{a}$ \\
Biocult & $1000 \mathrm{~b}$ & $5.83 \mathrm{a}$ \\
Glomus sp. 1054 & $1234 \mathrm{ab}$ & $5.90 \mathrm{a}$ \\
Vaminoc & $1013 \mathrm{~b}$ & $5.93 \mathrm{a}$ \\
LSD $(\mathrm{P}=0.05)$ & 416 & 0.25 \\
110R & & \\
Control & $1254 \mathrm{a}$ & $5.75 \mathrm{a}$ \\
Fungicide & $1317 \mathrm{a}$ & $5.75 \mathrm{a}$ \\
Biocult & $1075 \mathrm{a}$ & $5.70 \mathrm{a}$ \\
Glomus sp. 1054 & $1925 \mathrm{a}$ & $5.85 \mathrm{a}$ \\
Vaminoc & $1887 \mathrm{a}$ & $5.63 \mathrm{a}$ \\
LSD $(\mathrm{P}=0.05)$ & 973 & 0.26 \\
99R & & \\
Control & $2242 \mathrm{a}$ & $5.78 \mathrm{a}$ \\
Fungicide & $2838 \mathrm{a}$ & $5.90 \mathrm{a}$ \\
Biocult & $3004 \mathrm{a}$ & $6.05 \mathrm{a}$ \\
Glomus sp. 1054 & $3779 \mathrm{a}$ & $6.10 \mathrm{a}$ \\
Vaminoc & $2712 \mathrm{a}$ & $5.95 \mathrm{a}$ \\
LSD $(\mathrm{P}=0.05)$ & 1594 & 1.27 \\
\hline
\end{tabular}

a, b: Values accompanied by a common letter per rootstock do not differ significantly at the $5 \%$ level. 
The high spore concentration recorded for the $99 \mathrm{R}$ grapevines ranged between 2242 and 3779 spores/100 g dry soil, in comparison to $101-14 \mathrm{Mgt}$ and $110 \mathrm{R}$ grapevines where it never exceeded 2000 spores/100 g dry soil. This may be ascribed to the presence of cover crops (grain sorghum) that were sown annually between rows of the $99 \mathrm{R}$ vines. The cover crop may have facilitated a vast network of AM hyphae and spores interconnecting the roots of the cover crops and vines (Graves et al., 1997). In contrast, no such network was possible in the ridged soils of the 101$14 \mathrm{Mgt}$ and $110 \mathrm{R}$ vines, due to the absence of cover crops and the annual removal of weeds at these sites (Meyer et al., 2004).

The sandy character of the $99 \mathrm{R}$ plots is another factor that might have contributed to higher spore concentrations at this sampling site. Observations regarding higher spore concentrations in sandy soils in comparison to heavier soils, such as the soils in which the 101-14 Mgt and $110 \mathrm{R}$ vines were planted, were also made in other studies (Bhardwaj et al., 1997; B. Bowman, personal communication, 2000).

\section{CONCLUSIONS}

This research clearly points to the importance of indigenous AM fungi in vineyard soils of South Africa. A wide range of AM species, producing an abundance of spores, might occur in a typical vineyard, depending on the soil management practices. These AM fungal taxa are similar to those recorded in vineyards of other countries by other workers.

Since it is difficult to predict the grapevine's response to inoculation in unsterile soils, this research underlines the importance of assessing the mycorrhizal status of a soil before inoculation is considered to avoid possible masking effects. It was found that inoculation is not required in soils containing adequate concentrations of efficient AM species. Adopting practices that encourage these fungal populations in soil is strongly recommended. Cover crop use may facilitate the formation of root-hyphal networks and enhance spore production.

\section{LITERATURE CITED}

Abbott, L.K. \& Robson, A.D., 1982. The role of vesicular-arbuscular mycorrhizal fungi in agriculture and the selection of fungi for inoculation. Aust. J. Agric. Res. 33, 389-408.

Allen, E.B., Rincon, E., Allen, M.F., PerezJimenez, A. \& Huante, P., 1998 Disturbance and seasonal dynamics of mycorrhizae in a tropical deciduous forest in Mexico. Biotropica 30(2), 261-274.

Bhardwaj, S., Dudeja, S.S. \& Khurana, A.L., 1997. Distribution of vesicular-arbuscular mycorrhizal fungi in natural ecosystems. Folia Microbiol. 42(6), 589-594.

Brundrett, M., Bougher, N., Dell, B., Groove, T., \& Malajczuk, N., 1996. Working with mycorrhizas in forestry and agriculture. ACIAR Monograph 32. Australian Centre for International Agricultural Research, Canberra.

Brundrett, M., Melville, L. \& Peterson, L., 1994. Practical methods in mycorrhiza research. Mycologue Publications, Guelph.

Egerton-Warburton, L.M. \& Allen, E.B., 2000. Shifts in arbuscular mycorrhizal communities along an anthropogenic nitrogen deposition gradient. Ecol. Appl. 10 (2), 484-496.

Franke-Snyder, M., Douds, D.D., Galvez, L., Phillips, J.G., Wagoner, P., Drinkwater, L. \& Morton, J.B., 2001. Diversity of communities of arbuscular mycorrhizal (AM) fungi present in conventional versus low-input agricultural sites in eastern Pennsylvania, USA. Appl. Soil Ecol. 16 (1), 35-48.

Gallaud, I., 1905. Études sur les mycorrhizes endophytes. Revue General de Botanique 17, 5-48, 66-83, 123-136, 223-239, 313-325, 425-433, 479-500.

Graves, J.D., Watkins, N.K., Fitter, A.H., Robinson, D. \& Scrimgeour, C., 1997. Intraspecific transfer of carbon between plants linked by a common mycorrhizal network. Plant Soil 192, 153-159.

Karagiannidis, N. \& Nikolaou, N., 1999. Arbuscular mycorrhizal root infection as an important factor of grapevine nutrition status. Multivariate analysis application for evaluation and characterization of the soil and leaf parameters. Agrochimica 43 (3-4), 151-165.

Karagiannidis, N., Nikolaou, N. \& Mattheou, A., 1995. Influence of three VAmycorrhiza species on the growth and nutrient uptake of three grapevine rootstocks and one table grape cultivar. Vitis 34 (2), 85-89.

Karagiannidis, N., Velemis, D. \& Stavropoulos, N., 1997. Root colonisation and spore population by VA-mycorrhizal fungi in four grapevine rootstocks. Vitis 36 (2), 57-60.

Menge, J.A., 1982. Effect of soil fumigants and fungicides on vesicular-arbuscular mycorrhizal fungi. Phytopathol. 72 (8), 1125-1132.

Menge, J.A., 1983. Utilization of vesicular-arbuscular mycorrhizal fungi in agriculture. Can. J. Bot. 61, 1015-1024.

Meyer, A.H., Valentine, A.J., Botha, A., Archer, E. \& Louw, P.J.E., 2004. Young grapevine response and root colonisation following inoculation with arbuscular mycorrhizal fungi. S. Afr. J. Enol. Vitic. 25 (1), 26-32.

Morton, J.B. "International Culture Collection of Arbuscular \& VesicularArbuscular Mycorrhizal Fungi (INVAM)." INVAM home page. 25 September 2001. http://invam.caf.wvu.edu/invam.htm, 28 November 2001.

Picone, C., 2000. Diversity and abundance of arbuscular-mycorrhizal fungus spores in tropical forest and pasture. Biotropica 32(4), 734-750.

Plenchette, C., Furlan, V. \& Fortin, J.A., 1983. Responses of endomycorrhizal plants grown in a calcined montmorillonite clay to different levels of soluble phosphorus. I. Effect on growth and mycorrhizal development. Can. J. Bot. 61, 1377-1383.

Possingham, J.V. \& Groot Obbink, J., 1971. Endotrophic mycorrhiza and the nutrition of grapevines. Vitis 10, 120-130.

SAS, 1990. SAS/STAT User's Guide, Version 6, Fourth Edition, Volume 2, SAS Institute Inc, SAS Campus Drive, Cary.

Schubert, A. \& Cravero, M.C., 1985. Occurrence and infectivity of vesiculararbuscular mycorrhizal fungi in north-western Italy vineyards. Vitis 24, 129-138.

Schubert, A., Mazzitelli, M., Ariusso, O. \& Eynard, I., 1990. Effects of vesiculararbuscular mycorrhizal fungi on micropropagated grapevines: Influence of endophyte strain, $\mathrm{P}$ fertilization and growth medium. Vitis 29, 5-13.

Schwob, I., Ducher, M. \& Coudret, A., 1999. Effects of climatic factors on native arbuscular mycorrhizae and Meloidogyne exigua in a Brazilian rubber tree (Hevea brasiliensis) plantation. Plant Pathol. 48, 19-25.

Shapiro, S.S. \& Wilk. M.B., 1965. An Analysis of Variance Test for Normality (complete samples). Biometrica 52, 591-611.

Soil Classification Working Group, 1991. Soil classification: A taxonomic system for South Africa. Memoirs on the Agricultural Natural Resources of South Africa No. 15. Dept. of Agricultural Development, Pretoria.

The Non-affiliated Soil Analysis Work Committee, 1990. Handbook of standard soil testing methods for advisory purposes. Soil Science Society of South Africa, Pretoria.

Vimard, B., St-Arnaud, M., Furlan, V. \& Fortin, J.A., 1999. Colonisation potential of in vitro-produced arbuscular mycorrhizal fungus spores compared with a root-segment inoculum from open pot culture. Mycorrhiza 8, 335-338.

Zar, J.H., 1981. Biostatistical Analysis. Prentice-Hall, Englewood Cliffs, New Jersey. 